\title{
Mr. Paradise and other Plays, de TenNessee Williams: APONTAMENTOS PARA UMA ANÁLISE FORMAL
}

\author{
Maria Sílvia Bettı \\ Universidade de São Paulo
}

Resumo

Este artigo discute as características formais da peça em um ato nas peças de Tennessee Williams reunidas em Mr. Paradise and Other Plays.

Abstract

This article analyzes the formal characteristics of the one-act plays by Tennessee Williams collected in Mr. Paradise and Other Plays.
Palavras-chave

Dramaturgia norte-americana; drama moderno; peça em um ato.

Keywords

American drama; modern drama; one-act play. 
A.

examinar os diferentes processos de superação formal do drama no contexto do teatro moderno, Peter Szondi dedicou um segmento às características da peça em um ato, estrutura frequente em parte considerável da produção dramatúrgica do século XX. Seu aspecto central - a representação de uma situação flagrada e apresentada em si, fora de qualquer progressão ou encadeamento causal de ações foi um dos recursos mais representativos para a figuração de questões como a alienação e o isolamento do indivíduo. Quando um arcabouço de ações dramáticas chega a ser esboçado na peça em um ato, seu ponto de partida se mostra, já, como um momento de culminação dramática que corresponderia, na comparação com a forma da tragédia, à catástrofe, prenunciadora da queda. Essa característica confere densidade à peça em um ato, colocando-a, não casualmente, numa situação de afinidade com mecanismos do conto, e aproximando-a simultaneamente da lírica moderna e até mesmo, em alguns aspectos, da chamada "dramaturgia do absurdo".

As possibilidades figurativas da peça em um ato são particularmente interessantes, se levarmos em conta a natureza do material que caracteriza o contexto histórico e social do século XX: por um lado, tem-se a prevalência de esquemas de vida e de trabalho que impõem a massificação, a alienação, o confinamento do indivíduo e, ao mesmo tempo, a diluição da individualidade; por outro, predominam os mecanismos de percepção e pensamento apoiados no individualismo.

Uma das consequências do isolamento do indivíduo no mundo moderno e contemporâneo é, no campo da dramaturgia, a inviabilização do material dialógico convencional, baseado em trocas verbais objetivadas pela subjetividade das personagens e formalizadas por meio do drama. ${ }^{1}$

Ocorre que, como observa Peter Szondi, o estilo dramático acaba conseguindo resistir ao próprio isolamento que tende a inviabilizá-lo quando, em decorrência

\footnotetext{
${ }^{1}$ Peter Szondi, Teoria do drama moderno, São Paulo, Cosac \& Naify, 2001, p. 113.
} 
de fatores externos, o silêncio e o monólogo que prevaleceriam são substituídos por relações intersubjetivas e por trocas dialógicas artificiais e impostas, constituídas em situações de confinamento. ${ }^{2}$

Assim, enquanto a característica principal do épico é a intenção sociológica e científica de refletir sobre a infraestrutura das ações em sua alienação objetiva, ${ }^{3} \mathrm{o}$ traço marcante do drama moderno que sobrevive nessas condições será o de figurar as situações de alienação e isolamento, passando por isso a coexistir com as próprias circunstâncias sociais que, em princípio, haviam colocado a forma do drama em questão. Abre-se, em decorrência disso, um caminho formal que assegura a longevidade dessa estrutura dramatúrgica moderna e que a torna frequente, como ressalta Szondi, em uma parcela considerável das dramaturgias que, no século XX, evitaram o movimento em direção ao épico. ${ }^{4}$

No drama moderno o sujeito converte-se no objeto central de representação. Não se trata do sujeito agente, capaz de arbitrar sobre seu próprio destino, mas de um sujeito enclausurado nos equívocos e impasses gerados por suas próprias percepções e pulsões. Para representá-los, o recorte situacional e o foco nos desencontros dialógicos, usuais na peça em um ato, revelaram-se recursos poderosamente carregados de possibilidades.

Tennessee Williams, cujo centenário de nascimento foi comemorado precisamente no ano de 2011, foi um dos mais prolíficos autores de peças em um ato da dramaturgia norte-americana, tendo escrito, ao longo de sua carreira, cerca de setenta delas. Seu apreço por essa estrutura ligava-se ao fato de ela proporcionar um campo fértil para experimentações, fornecendo-lhe material para expansões e aprofundamentos posteriores.

Como ele cultivou com regularidade a produção literária também nos demais gêneros - a poesia e a ficção -, várias de suas peças em um ato foram transformadas em contos e/ou poemas, ou, em outros casos, extraíram deles matéria-prima para a sua criação.

A maior concentração de peças em um ato no trabalho dramatúrgico do autor data dos dois períodos extremos de sua carreira: a fase inicial, entre as décadas de 1930 e 1940, quando ele começava sua ascensão profissional, e, em menor escala, a do final dos anos 1960 e a primeira metade da década seguinte, quando ele passou a ver-se duramente fustigado pela crítica, acusado de incorrer em repetições de trabalhos anteriores e de enveredar por escolhas estilísticas e formais malsucedidas.

Dentro da extensão de seu trabalho e da diversidade de formas e gêneros que praticou sempre, Tennessee revelou-se um observador inquieto das rupturas que marcaram o teatro no século XX, e das transformações e crises que abalaram a base da sociedade à sua volta. Em um ambiente teatral como o norte-americano, cujas balizas eram um naturalismo cênico arraigado, de um lado, e uma insopitável

\footnotetext{
${ }^{2}$ Idem, ibidem

${ }^{3}$ Idem, ibidem, p. 136.

${ }^{4}$ Idem, ibidem, p. 113.
} 
afinidade com Hollywood e com as grandes mídias, de outro, essa não foi uma opção fácil e nem confortável, a despeito de sua enorme celebridade.

O compromisso com a condição de autor comercialmente agenciado no campo dos espetáculos e no mundo editorial trouxe-lhe sempre a imposição inexorável de uma produção constante, desdobrada em paralelo ao acompanhamento das centenas de adaptações de originais seus para o cinema e a televisão em todo o mundo.

Diante da engrenagem empresarial e midiática que consolidou sua canonicidade, o campo das peças em um ato parece ter representado um território até certo ponto indene ao imediatismo e à voragem da demanda produtiva que envolveu o autor: parte considerável delas só veio a ser encenada postumamente, por ocasião de festivais e de eventos destinados à celebração de sua memória. No campo editorial muitas só seriam publicadas postumamente, em edições antológicas compiladas a partir de diferentes critérios de organização.

Se essas características fazem das peças em um ato objetos de interesse para uma análise da dramaturgia do autor, a copiosidade e a diversidade delas tornam praticamente inviável a tarefa de estudá-las como tema de uma abordagem monográfica ou generalizante. Seria necessário submetê-las a diferentes recortes analíticos, seja segundo o critério da matéria representada, seja sob o da natureza do gênero dramatúrgico e da forma propriamente dita.

\section{II}

Para aquilo a que se propõe este artigo, o material das peças em um ato de Tennessee Williams será discutido a partir do exame de alguns dos componentes formais do conjunto de textos reunidos na edição de Mr. Paradise and other plays, ${ }^{5}$ lançada originalmente em 2001, nos Estados Unidos, e relançada em 2005.

Dentre as peças que integram esse volume, o maior número data precisamente da década de 1930, quando foram escritas Por que você fuma tanto, Lily? (1935); Verão no Lago; O Matadouro Municipal; O grande jogo; e O Palooka (1937); Adão e Eva numa balsa; Mr. Paradise; e A mulher do gordo (1939). Fuga foi escrita presumivelmente entre 1939 e os primeiros anos da década seguinte, de que também datam Estas são as escadas que você tem que vigiar e Obrigada, Bom Espírito (1941), e finalmente $O$ quarto rosa (1943). E contar tristes histórias das mortes de travestis não teve a data de sua criação definida com segurança pelos pesquisadores, mas remete presumivelmente ao período entre 1958 e $1962 .{ }^{6}$

O predomínio dos focos situacionais em detrimento do encadeamento dramático padrão se apresenta, desde uma primeira leitura, como o traço principal em todo o conjunto de peças do volume. O tratamento a que Tennessee submete seus mate-

\footnotetext{
${ }^{5}$ Tennessee Williams, Mr. Paradise and other plays, Nova York, New Directions Publishing, 2005.

${ }^{6}$ Todas as citações feitas neste artigo foram traduzidas a partir das peças reunidas em Mr. Paradise and other plays.
} 
riais é inequivocamente lírico ou lírico-épico, e quando alguma progressão narrativa chega a se apresentar, uma densa impregnação de lirismo ou uma sutil corrosão por ironia vem dissolver prontamente a possível prevalência de qualquer cerne dramático residual. Se em alguns momentos específicos alguns nós conflituais parecem emergir, eles se desvanecem rapidamente ou encapsulam-se no beco sem saída da irresolução estrutural. Os diálogos compõem-se de trocas verbais de cunho predominantemente reticente e elíptico. As falas se mostram frequentemente rarefeitas e muitas vezes afastam-se provocativamente da coloquialidade que lhes poderia, em princípio, ser cobrada. Muitas das rubricas alongam-se para muito além da funcionalidade cênica e enveredam por uma esfera de expressão claramente literária.

Por que você fuma tanto, Lily?, que tem o significativo subtítulo de "Um conto em um ato", é, dentre as peças reunidas no volume, um dos textos mais representativos da proximidade que a escritura de Tennessee Williams apresenta com a ficção, ilustrando assim várias das características apontadas antes. Grande parte das rubricas alusivas às personagens é empregada na composição de elementos figuráveis apenas com o uso de sugestões de caráter simbólico. Podem-se citar alguns exemplos tomados à apresentação descritiva de Mrs. Yorke, uma das duas personagens da peça:

Cada movimento seu está impregnado da vaidade um tanto quanto aversiva que caracteriza a robustez de meia idade. ${ }^{7}$

Suas mãos fazem movimentos rápidos como se fossem grandes pombos brancos, e seus pesados braceletes e brincos de pingentes fazem o barulho dos arreios de um pônei que trota. ${ }^{8}$

Uma voz narrativa parece apropriar-se do que seria, em princípio, o campo técnico e informativo das didascálias, impregnando-o com recursos de uma caracterização que só se constitui plenamente no ato da leitura literária, e que não pode ser plenamente captada dentro da especificidade da interpretação dramática.

Essa natureza híbrida está presente em indicações didascálicas referentes à própria personagem aludida no título nessa mesma peça:

LILY - (Seus olhos, colorindo-se de um verde brilhante e atormentado): Meu Deus, Mãe. O que mais eu posso fazer? ${ }^{9}$

[...]

A risada de Lily produz espasmos dolorosos entre as baforadas de seu cigarro trêmulo. Ela parece estar tentando parar o riso com a fumaça, como água esborrifada inutilmente sobre chamas ardentes. O riso continua e agita seu corpo delgado. ${ }^{10}$

7 Idem, ibidem, p. 47.

8 Idem, ibidem.

9 Idem, ibidem, p. 47.

${ }^{10}$ Idem, ibidem, p. 50. 
Adão e Eva numa balsa é constituída por um material que também remete ao campo da escritura literária: uma de suas duas personagens é explicitamente composta a partir da apropriação ficcional de traços da personalidade do escritor britânico D. H. Lawrence, por cuja obra e biografia Tennessee nutriu sempre grande admiração e interesse. Não pode haver dúvida, por parte de quem assiste ou lê a peça, sobre a identidade apenas simbolicamente sugerida da persona dramatúrgica do romancista inglês. Mas é no âmbito textual da rubrica que a remissão a ele ganhará maior explicitação, projetando-se em cena sob a forma icônica da fênix entre chamas ardentes numa tapeçaria na parede:

Cena: Varanda fechada de uma casa de campo nos Alpes Marítimos. Há várias plantas em vasos, e na parede de trás uma tapeçaria mostrando a figura tecida de uma fênix em um ninho de chamas, que vem a ser o símbolo pessoal do homem de barba ruiva sentado na cadeira reclinável. Ele traja um robe de cetim dourado com um xale de tricô cor de alfazema sobre os ombros, e está fazendo um bordado delicado quando a cortina sobe $[\ldots]^{11}$

Não só a estrutura de composição desse Lawrence ficcional dramaturgizado, mas todo o liame relacional entre ele e a outra personagem da peça, uma visitante norte-americana, apoiam-se decisivamente nas características tidas como fundamentais da ficção do romancista: a impregnação erótica latente na base das relações humanas, e o profundo efeito desumanizador exercido pelas regras herdadas de convívio em sociedade. No espaço aparentemente realista do retiro alpino do escritor, Tennessee compõe um Lawrence exoticamente vestido e emblematicamente entretido na tessitura de um bordado revelador:

LAWRENCE: Vou continuar com meu bordado. Gosta deste desenho?

VISITANTE: O que é isso?

LAWRENCE: O macho e a fêmea originais. Está vendo como sou depravado? Chego a colocar sexo na minha costura. ${ }^{12}$

Ariadne Peabody, a visitante, procura o romancista, de fato, à espera de uma revelação: sente-se presa à lembrança obsessiva da atração que a impulsionara para os braços de um desconhecido num percurso de balsa entre Oakland e San Francisco dois anos antes. O nome e o endereço que o homem sussurrara ao seu ouvido ao final do percurso apagaram-se misteriosamente de sua memória, e seu corpo agora transforma em dor insuportável a nostalgia do toque das mãos dele.

Refém dessa situação insolúvel, a moça espera que Lawrence a ajude a resgatar as lembranças reprimidas para que possa reencontrar o desconhecido da balsa, e é ouvida pelo escritor de maneira aparentemente displicente e pouco objetiva. $\mathrm{O}$ aclaramento final não resulta de uma análise convencionalmente conduzida, mas do fio tortuoso de um diálogo que só entra efetivamente no assunto em foco após

${ }^{11}$ Idem, ibidem, p. 169.

${ }^{12}$ Idem, ibidem, p. 172. 
esgotar-se a série de pedidos extravagantes e aparentemente despropositados feitos à moça pelo romancista. Atarantada no atendimento deles, ela expõe mais de si do que percebe, e fornece ao perspicaz olhar de seu interlocutor elementos que irão colocá-lo no papel de condutor do jogo dedutivo que se inicia:

LAWRENCE: Fale do seu amante.

VISITANTE: Não tenho nenhum.

LAWRENCE: Bobagem. Todo mundo tem, mesmo que seja um par de chinelos velhos. O que me diz daquele homem que você conheceu há seis anos atrás num mês de agosto?

VISITANTE: Dois anos atrás!

LAWRENCE: Tão pouco tempo assim?

LAWRENCE: Como é que o senhor sabe?

LAWRENCE: A sombra dele ainda pode ser vista nos seus olhos. [... $]^{13}$

Ao presumivelmente demandar do público uma familiaridade prévia com a figura do Lawrence real e de seu trabalho literário, a peça ganha um tom de “divertissement" intertextual. É ilustrativo desse aspecto o comentário do Lawrence-personagem acerca da ingenuidade deletéria de Ariadne:

LAWRENCE: $[$...] Chegou às vias de fato?

VISITANTE: Do que?

LAWRENCE: Do ato.

VISITANTE: Que ato, Mr. Lawrence?

LAWRENCE (com um largo sorriso satírico): Ahh - Senhorita Inocência!

VISITANTE: Não foi um ato, Mr. Lawrence, foi somente um encontro.

LAWRENCE: Hummmm. O efeito pernicioso do intelectualismo estéril outra vez. Lá atrás, quando o mundo era jovem e o homem era um animal de sangue quente, todo encontro resultava em um ato de um tipo ou de outro. Agora os encontros são só pequenas reverências rígidas e sorrisos hipócritas, e uma pequena conversinha sobre o clima. Todo o natural veneno saudável que temos nas nossas naturezas, ao invés de ser expresso de modo imediato e espontâneo em briguinhas de vizinhos, é armazenado em um tipo de reserva nacional até se tornar conveniente que os chefes de estado o liberem na insanidade em grande escala que é a guerra. Tudo porque não é mais considerado adequado dar um tapa na cara de um homem porque você não gosta dos traços dele, ou atirar uma garota numa vala porque você gosta muito dos dela. Mas estou saindo um pouco do assunto, não é? [... $]^{14}$

Há uma inegável ironia de sabor paródico no fato de Ariadne, ao contrário de sua homônima mitológica, ser ela própria a enclausurada, e não a detentora do fio que conduzirá para fora do labirinto. Mas o que parece ganhar força, ao final, é a sugestão sutil de que, diante da fértil sagacidade criadora de Lawrence, Ariadne se mostre, por fim, não como mulher de carne e osso, mas como projeção ficcional da mente do escritor corporificada em cena.

${ }^{13}$ Idem, ibidem, p. 173.

${ }^{14}$ Idem, ibidem, p. 174. 
Não é apenas pelo flanco da ficção, entretanto, que Tennessee Williams adentra na seara da literatura não dramática no conjunto de peças em um ato do volume em questão: a afinidade com a poesia é material tratado centralmente na forma e na matéria dentro do texto que dá título ao volume: Mr. Paradise: veleidades poéticas da juventude haviam levado Jonathan Jones, em algum momento do passado, a publicar um pequeno livro de versos sob o pseudônimo constrangedoramente simplório de Anthony Paradise. Várias décadas se passaram, e agora, maduro e solitário, vivendo num quarto no decadente bairro boêmio de Nova Orléans, ele é procurado por uma jovem estudante da elite local que, tendo encontrado acidentalmente um dos exemplares do livro em um antiquário da cidade, acredita-se imbuída da missão de revelar ao mundo a suposta grandeza do poeta esquecido.

A peça desenvolve-se a partir da conversa travada no momento em que Jones se vê diante da inesperada visita: sua perplexidade inicial dá lugar a uma indisfarçável irritação diante da desconhecida entusiasmada e ingênua, mas ainda assim invasiva. Os diálogos são alavancados inicialmente pelo contraste: as falas de Jones são contidas, lacônicas e marcadas por um mordente de sarcasmo; as da Jovem derramam-se na vibração de um entusiasmo generoso, mas pueril, e sem dúvida, precipitado. Jones raciocina, de início, dentro da materialidade e da situação concreta em que vive; já a Jovem, imbuída de um alto grau de idealização da arte, mostra-se absurdamente alheia à realidade social dos meios artísticos e literários no próprio ambiente em que vive, em meio a uma classe que tem acesso aos bens culturais em razão, precisamente, de seu próprio poder de compra:

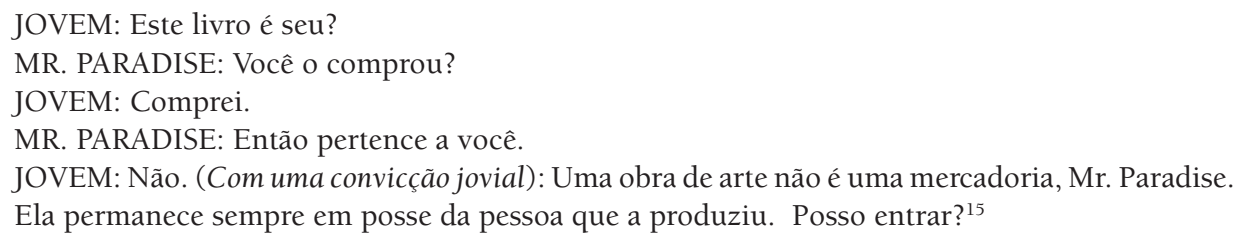

A base formal é simples e apoia-se numa sucessão de diálogos em que nenhum dos dois interlocutores se revela isento de contradições. A oportunidade de supostamente resgatar Anthony Paradise do esquecimento afigura-se, para a Jovem, como circunstância capaz de ressignificar sua vida, livrando-a do tédio das reuniões sociais a que a mãe a arrasta, e ligando-a, possivelmente, à aura de reconhecimento literário que, imagina, virá a constituir-se em torno dele.

Essa expectativa contrasta, porém, com a situação presente de Jones: nada indica que ele tenha, ao longo do tempo decorrido, dado continuidade ao trabalho poético que iniciara como Anthony Paradise na juventude, ou que o tenha feito sob qualquer outra identidade. O grau de afinidade entre os dois interlocutores é mínimo: a Jovem não é capaz de entender a resposta irônica de Jones diante de sua

${ }^{15}$ Idem, ibidem, p. 19. 
insistência; Jones, que ouve o longo e caloroso relato que ela lhe faz, procura inutilmente dar-lhe a entender que Paradise é, na fase atual de sua vida, um estranho com o qual ele nada mais tem em comum.

A peça funciona, assim, como um verdadeiro desfiar de insucessos comunicativos entre as duas personagens, colocadas uma diante da outra em total ausência de pontos em comum e em contraste total quanto à classe social, à idade, à visão de mundo, à forma de expressão e raciocínio e às expectativas para o futuro. Da conversa entre a Jovem e Jonathan Jones nenhum conflito e nenhuma ação dramática stricto sensu decorrem: o único pacto estabelecido entre ambos não resultará da concordância dele ante a ideia de ser "resgatado" e propelido para uma vida de compromissos editoriais, sociais e acadêmicos, e sim de sua crença no valor e na força vital da poesia num mundo onde prevalecem o lucro e os artefatos bélicos:

JOVEM: O senhor não pode ser Anthony Paradise agora? De novo?

MR. PARADISE: Não. Não, é tarde demais. Estou velho demais. A morte é a única coisa que talvez possa salvar minha reputação. Volte à escola, mocinha. Tudo tem um fim, até o suprimento de pólvora. Quando estiverem exaustas, as pessoas vão começar a procurar outra vez, debaixo de pernas de mesas quebradas, por pequenos livros de versos esquecidos. Até lá, Jonathan Jones já estará fora do caminho a salvo. O sol brilhará num céu claro e azul. O vento soprará as folhas do alto das montanhas. Crianças brincarão na areia das em praias claras e ensolaradas. O mundo estará caloroso, sereno, e tão jovem quanto o amanhã. E assim, então, todas as velhas, doces e gentis vozes serão trazidas de volta e percebidas outra vez. Você escutará o vento nas árvores, a chuva no telhado, e as canções dos poetas há muito esquecidos. Bombas explodem e destroem e são destruídas. Mas isto - estas pequenas canções, por pequenas e pouco importantes que sejam, continuam cantando para sempre. Às vezes, se escondem atrás da lua, como o sol num eclipse Elas têm seus períodos de eclipse. Mas elas ressurgem. Mas num determinado momento surgirão novamente. O movimento da vida é ascensional, já o movimento da morte é para baixo. Apenas o mais cego de todos os pobres cegos tolos não é capaz de enxergar em tal elevação aquilo que vai estar finalmente no ponto mais alto! Não a morte, mas a vida, minha querida. Vida - vida. Não os deixarei acabar com a vida para sempre! Eu os desafio a interrompê-la para sempre! Não com todas as suas armas, não com toda a sua destruição! Vamos continuar cantando. Um dia, toda a superfície terrestre cantará e o ar por toda a terra estará repleto do nosso canto.

A glória que a Jovem almeja para Mr. Paradise não condiz com o presente cinzento e decadente de Jones. O Paradise idealizado não pode coexistir com o amargo e cínico Jones, como esse bem sabe, e será preciso que o Jones do presente morra para que o Paradise do passado possa reviver. É irônico, portanto, o desfecho, já que acaba prevalecendo, no plano imediato, o atendimento literal e ingênuo da moça à recomendação cínica de seu interlocutor:

JOVEM: Talvez o senhor esteja certo. Vou fazer o que o senhor falou, guardar o livro e lembrar seu nome -

MR. PARADISE: E ler as colunas dos obituários!

JOVEM: É. E quando chegar a hora - pode contar comigo, Mr. Paradise.

MR. PARADISE: Obrigado, minha querida. Eu vou contar com você. ${ }^{16}$

${ }^{16}$ Idem, ibidem, p. 25. 
A defesa apologética da poesia e o vislumbre de um mundo futuro em que o som das bombas cede ao das vozes que cantam impressionam a Jovem e demovem-na sutilmente de resgatar Paradise, pelo menos por ora. O entusiasmo da moça pela poesia é habilmente preservado pelo ex-poeta, mas a forma como isso ocorre reforça a própria ironia com que Jones - e com ele o espectador - ouve suas palavras de despedida:

JOVEM: Eu prometo, não vou decepcioná-lo. Seu futuro está a salvo nas minhas mãos. E agora, Mr. Paradise - pode me dar um beijo de despedida?

MR. PARADISE: Não.

JOVEM: Por que não?

MR. PARADISE: Não. Pela mesma razão que eu não tocaria uma toalha de mesa branca e limpa com - os dedos sujos de lama.

JOVEM: Ah. (Estende a mão gravemente) Adeus, Mr. Paradise.

Assim como em Adão e Eva em uma balsa, a ironia em Mr. Paradise resulta da defasagem de percepções das duas personagens, e das discrepâncias entre o sentido explícito, enunciado nos diálogos, e o figurado, subjacente e compartilhado pelo espectador/leitor.

\section{III}

A principal dificuldade interpretativa e analítica desse tipo de dramaturgia reside na sutil desagregação que apresenta dos sentidos exteriormente sugeridos: embora a tessitura de diálogos seja a base, o aspecto mais expressivo da matéria representada encontra-se nos desníveis de comunicação que eles produzem, nas suas elipses de pensamento e desencontros de percepção, requerendo assim uma apurada "sintonia fina" por parte do leitor que a analisa e dos atores que a interpretam em cena.

A mulher do gordo e O quarto rosa fornecem aspectos que ilustram e confirmam essa característica. Não casualmente, Tennessee envereda, em ambas, pelo terreno da comédia social, em que personagens de classe média lidam com o processo não assumido de desgaste de suas relações afetivas e conjugais.

Em A mulher do gordo, Joe, um bem-sucedido produtor teatral nova-iorquino, e sua mulher Vera, ambos de meia-idade, trocam impressões sobre a elegante festa de Ano-Novo de que acabam de voltar. O bom humor ligeiramente inebriado de Joe contrasta com o indisfarçável tédio de Vera. Ambos, durante a festa, flertaram com pessoas mais jovens que se iniciam na carreira artística: Joe com Esmeralda, uma atriz na qual Vera não reconheceria nenhum outro talento que o de mostrar as pernas em espetáculos de variedades, e Vera com Dennis Merriwether, um bem-sucedido dramaturgo principiante que Joe chama de "idiota" por ter recusado uma oferta milionária da Metro Goldmeyer e acusado a Broadway de "assassinar" um original seu.

A troca mútua de farpas entre Joe e Vera estende-se de modo a deixar evidente que os ciúmes e a irritação são as únicas formas de reação que ainda conseguem 
despertar um no outro. Para Vera, o trabalho de Esmeralda no papel da protagonista da peça de Merriwether produzida por Joe teria "profanado" a montagem. Para Joe, Merriwether não passa de "um menino" e de um "caipirão", desprovido do comospolitismo europeizante que suas próprias peças poderiam, em princípio, fazer esperar.

Vera não esconde o fato de lamentar a recusa de Dennis ao contrato milionário da Metro, mas afirma que "é bom saber que ainda existem pessoas que o dinheiro não consegue comprar". Joe, por sua vez, atribui o fato de o trabalho de Merriwether ser bem visto pelos críticos à "sorte" do rapaz, que acredita (e provavelmente augura) efêmera.

Toda a sequência inicial de trocas verbais entre as duas personagens serve ao propósito da configuração de seu perfil e contexto. Joe e Vera travam diálogos irônicos e paradoxais: existe tensão considerável entre os dois, mas essa cristaliza-se em um equilíbrio estático, fruto da inexistência de qualquer forma efetiva de crise que potencialize a ruptura:

\footnotetext{
VERA - Às vezes eu me pergunto por que eu não te deixo, Josie. Esta seria uma solução.

JOE - Bem, então porque você não me deixa? Você vem ameaçando fazer isso nos últimos quinze ou vinte anos.

VERA - Há sempre um novo dia. E você é sempre tão bem-humorado de manhã, Josie, que fica impossível eu retomar o humor da noite anterior. Acho que se a gente tiver que se livrar um do outro vai ter que ser de repente, de noite, sem nos despedirmos. O hábito é uma força tão avassaladora! $[\ldots]^{17}$
}

As palavras de Vera nessa fala preparam terreno para a cena que se segue: Joe, ansioso por encontrar Esmeralda, sai em plena madrugada com o pretexto de comprar aspirinas. Na ausência dele, Vera recebe a inesperada visita de Dennis Merriwether que, movido pela paixão, vem com o intuito expresso de declarar-se a ela e de lhe propor que partam juntos para Acapulco ao amanhecer. Dennis é afetuoso e ardente, seus argumentos apelam ao anticonvencionalismo e ao desejo de ruptura de Vera; e sua fala, pontuada por imagens idílicas, anuncia o enlevo de momentos íntimos em viagens aventurosas por mares distantes e praias desertas.

As circunstâncias são propícias à separação sem dúvida desejada por ela. Tudo parece prenunciar a instauração da crise e o rompimento subsequente com a monotonia conjugal. Mas o que prevalece, por fim, é o princípio internalizado da acomodação e do interesse, solidamente revestido com os princípios do bom senso e da análise racional dos fatos:

VERA - Você é um garoto. - Eu sou uma mulher de meia-idade.

DENNIS - Você nunca será de meia-idade.

VERA - Este é o comentário mais gentil que um homem já fez para uma mulher, e o mais falso! - Quantos anos você tem, Dennis?

${ }^{17}$ Idem, ibidem, p. 126. 


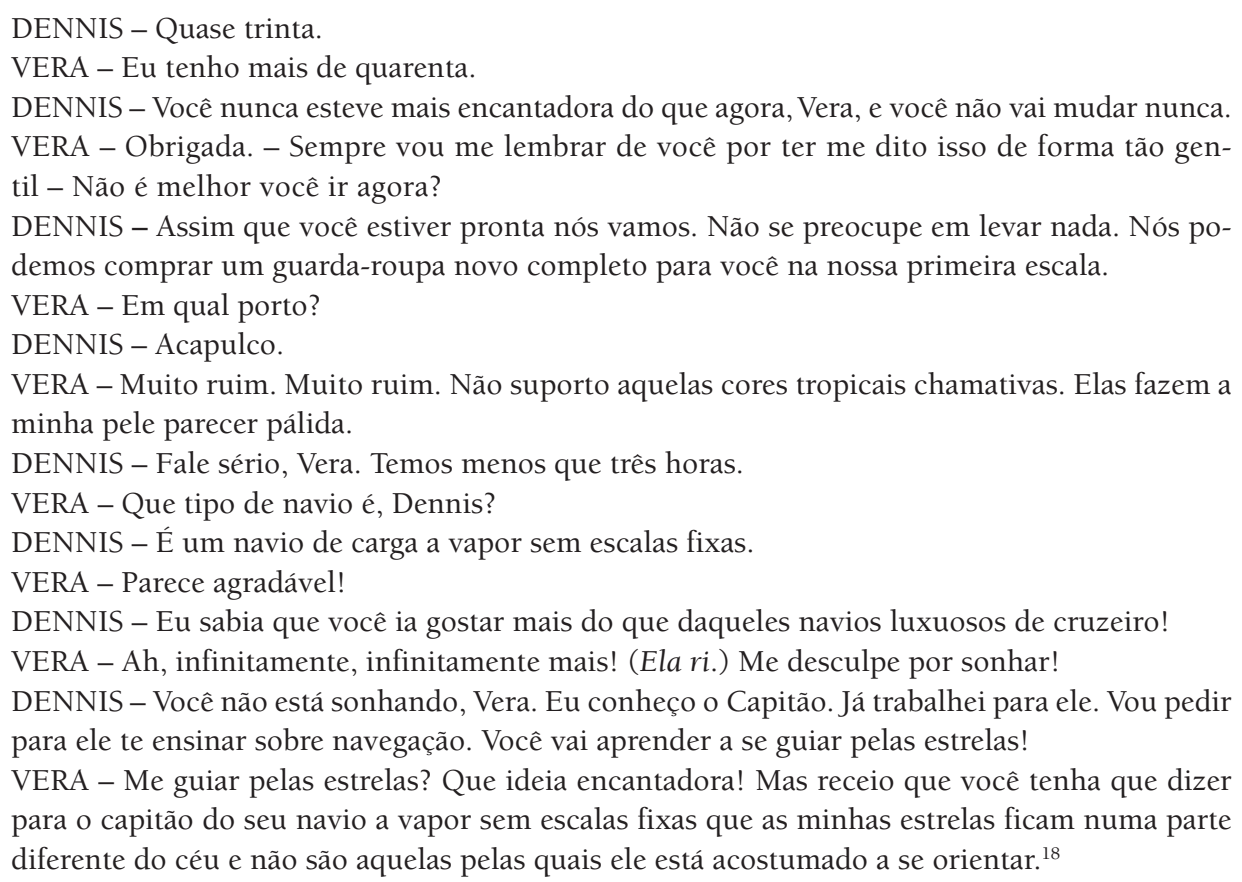

A expectativa do leitor/espectador desavisado esvazia-se radicalmente aqui. Diante do tom irônico e desencantado de Vera, o argumento central de Dennis com o intuito de convencê-la acaba sendo inócuo:

DENNIS - Vera, seu marido é gordo. Não só fisicamente gordo. Mas mentalmente. Ele é mentalmente gordo e - e eu ouvi uma mulher na festa esta noite perguntando para outra quem você era, e a mulher riu e disse, "Ah, ela é só a mulher do gordo!" - Me doeu muito pensar que alguém pudesse identificar você - você, Vera! - como sendo simplesmente a mulher do gordo que estava se passando por imbecil naquela festa! ${ }^{19}$

A figura inusitada do homem "mentalmente gordo", de que Dennis se utiliza, apresenta uma interessante carga crítica ao estabelecer uma correlação simbólica entre o traço físico do excesso (a gordura) e a mente, sede do intelecto, fazendo pensar assim na ideia de alguém para quem o acúmulo desarrazoado é um traço constitutivo em todos os níveis. Qualquer associação que se estabeleça entre essa figura e a de uma alta classe média consumista para quem o dinheiro franqueia tudo não será descabida.

Paralelamente, o próprio raciocínio implícito no argumento de Dennis não deixa de revelar um grau considerável de endosso aos estereótipos sociais dominantes, já que ele se apoia na suposição de que, para Vera, a possibilidade de ser vista pelos

${ }^{18}$ Idem, ibidem, p. $134-5$.
${ }^{19}$ Idem, ibidem, p. 137. 
demais como "simplesmente a mulher do gordo que estava se passando por imbecil" pudesse ser mais convincente do que o próprio valor afeto propriamente dito.

A simplicidade de concepção da estrutura dramatúrgica guarda uma sutil armadilha para quem a lê ou interpreta: Dennis mostra-se refratário diante do recém-alcançado sucesso, o que sugere uma possível (mesmo que ingênua) recusa aos aspectos tentadores do sistema. Ainda assim, ele não hesita em apelar para um argumento desprovido de senso crítico diante do que presume ser a opinião corrente: "me doeu muito pensar que alguém pudesse identificar você..." etc.

São, entretanto, Vera e Joe que se encontram no foco central da representação, e a forma como interagem e raciocinam expõe fragorosamente a ausência de integridade e de coerência que os caracteriza. A função de Dennis como personagem é, assim, a de apresentar um contraponto às perspectivas e aos valores por que se pauta o casal, ressaltando-lhes a inconsistência e a futilidade sem que ele próprio, Dennis, passe incólume pela lente crítica que a peça apõe sobre o ambiente social e cultural da classe a que pertencem.

O quarto rosa apresenta um processo análogo na natureza dos diálogos e na matéria representada. Tem-se novamente um casal, mas inserido, aqui, no delicado campo das ligações extraconjugais: um homem de meia-idade mantém uma amante num aconchegante ninho de amor clandestino, e encontra-se com ela a pretexto de viagens de negócios.

O local de encontros foi inteiramente revestido de materiais na cor rosa a fim de sugerir uma atmosfera sensual e glamourosa, propícia ao enlevo amoroso. Os amantes atuam de forma extremamente fiel aos papéis que assumiram entre si: a moça, bela loira de trinta anos, veste-se de maneira provocante; o homem, mesmo quando ausente, manda-lhe flores e cartões com palavras de amor.

Trata-se, na verdade, de uma relação não recente e a essa altura já totalmente estabilizada, e os arroubos amorosos do início converteram-se numa sequência de protocolos cuja observância é rigorosamente cobrada entre os dois. O homem, ao chegar, contempla com cansaço a saturação cromática do ambiente e afere se as flores que enviou foram devidamente recebidas. A amante, fria e visivelmente ressentida, responde de forma lacônica: o vaso de bicos-de-papagaio recebido provavelmente lhe parece redundante e vulgar, em plena época de Ano-Novo, quando a onipresente decoração festiva se mostra repleta de arranjos florais análogos.

O homem recentemente ausentou-se do ninho de amor, na passagem do ano, alegando um evento com clientes em Chicago. A amante cobra-lhe explicações, pois ele teria sido visto por uma conhecida numa orgia de casais num hotel da cidade. As falas da amante são pontuais e marcadas pela ironia. As dele são evasivas e defensivas, mas ele admite mentir com o intuito de não vê-la enfurecer-se.

O desencontro de expectativas mútuas repercute fortemente na estrutura dos diálogos, evocando certas elipses que parecem antecipar o chamado "teatro do absurdo":

HOMEM - Tudo que eu falo você diz que é mentira!

MULHER - Só quando eu tenho - 


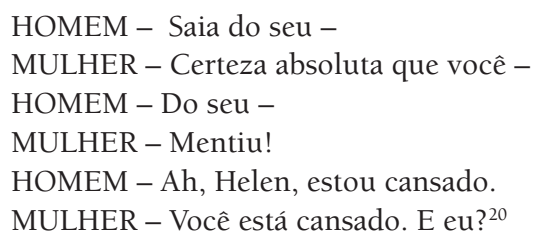

A amante sente-se preterida, alega ter aberto mão de sua vida social a fim de estar sempre disponível para os possíveis encontros, e cobra dele uma opção final entre ela própria e a esposa. O homem, por sua vez, mostra-se exaurido pelas pressões profissionais e afetivas, e acusa a amante de possessividade e egoísmo.

O ninho de amor proibido tornou-se, ao longo do tempo, uma espécie de réplica do que o próprio lar conjugal tem de menos desejável: o tratamento afetivo dispensado pelo homem à amante é, sintomaticamente, "Mãezinha". E o descompasso comunicativo nos diálogos segue um crescendo estrutural que culmina com a quase completa desagregação da lógica nas trocas verbais:

MULHER - A história se repete. Eu já sabia que isso ia acontecer. Mais uma vez você se sente um pedaço de carne por causa de uma mulher! Há oito anos foi ela. Hoje sou eu que destruo seus sonhos. O mundo dá voltas e tudo volta aonde começou. É verdade. Você bateu na minha porta cheio de insatisfações.

HOMEM - Rosa-rosa-rosa...

MULHER - Ah, você se esqueceu o estado em que você estava naquela época!

HOMEM - Tudo - rosa-rosa-rosa...

MULHER - Você estava tão mórbido e neurótico -

HOMEM - As paredes, o teto, o carpete -

MULHER - Você até falou em suicídio!

HOMEM - São todos rosa-rosa-rosa.

MULHER - Ah, como você sofria em casa com aquela mulher egoísta, sua -

HOMEM - Rosa!

MULHER - Esposa!

HOMEM - Tudo rosa - a cama - os travesseiros -

MULHER - E a minha vida então? Completa! Estava a caminho do sucesso! Com certeza! Jovem.

HOMEM - Cortinas rosa! Abajur rosa! ${ }^{21}$

Ainda que a natureza da matéria representada pertença ao âmbito tipológico da comédia social em sua acepção mais típica, os estereótipos associados a esse subgênero dramatúrgico não sobrevivem à radical e crescente erosão da coerência dos diálogos:

MULHER - Agora me deixa de lado! Se aquilo não era casamento, eu não sei o que casamento é. E o homem se iguala aos cachorros!

HOMEM - Rosa-rosa-rosa!

${ }^{20}$ Idem, ibidem, p. 105-6.

${ }^{21}$ Idem, ibidem, p. 112-3. 


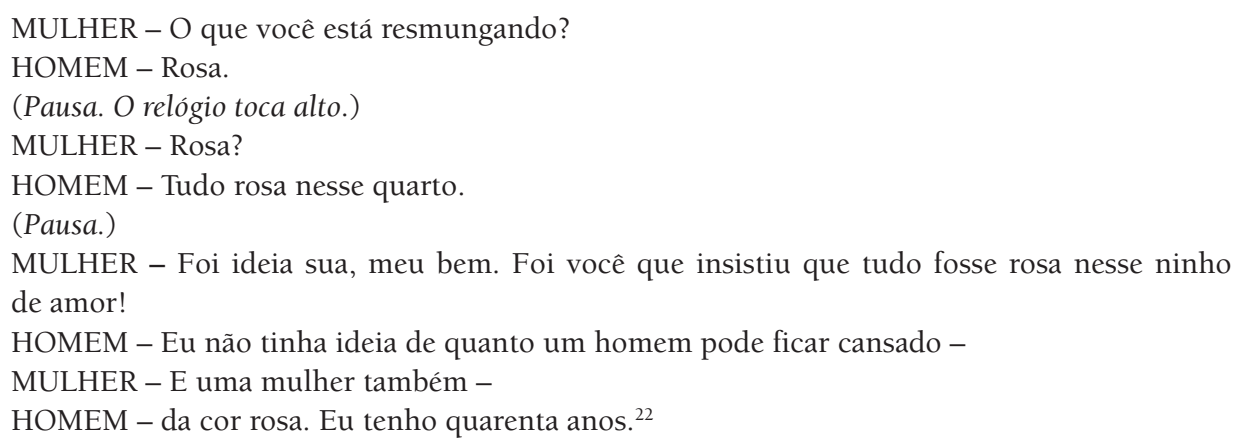

Dentro da estereotipia formal desmantelada, desmantela-se também a percepção que o bloco inicial de diálogos construíra no leitor/espectador, e o próprio desfecho provavelmente antevisto: o homem evasivo que parecia ter já um pé fora da relação amorosa reluta ao ver-se sumariamente expulso do nicho de amor pela amante. A cor rosa, ironicamente, acaba servindo de pivô ao argumento da moça ao pedir peremptoriamente ao homem a devolução da chave, sinalizando assim, ela própria, o fim da relação.

A estrutura da peça funciona na contramão de seus próprios sentidos iniciais e aparentes, o que acontece pela surpresa que se apresenta, ao final, quando se constata que a moça queixosa e enciumada do início tinha já um amante novo devidamente instalado no ninho amoroso, e que não cederá ao apelo insistente do amante anterior, que toca inútil e intermitentemente a campainha enquanto a cortina desce. A peça produz, assim, uma reversão das expectativas óbvias, ativando, em decorrência disso, um processo crítico que desagrega a convencionalidade que parecia caracterizar a sua escritura.

Como em A mulher do gordo, não é a relação amorosa o objeto da representação, mas as erosões, fissuras e idealizações que a esvaziaram, e especialmente a impregnação viciosa dos estereótipos sociais e sexuais que a distorceram de modo fatal.

A natureza do trabalho formal praticado nesse tipo de dramaturgia requer a apreensão minuciosa e atenta desses processos sob o risco de fixar, na leitura e na interpretação, apenas a exterioridade temática de que se reveste o material efetivamente trabalhado.

\section{IV}

Uma das características da dramaturgia de Tennessee Williams no campo da peça em um ato é a do grande rendimento que ele consegue extrair da sua concisão estrutural. A condensação inerente a essa forma dramatúrgica dá margem, em sua produção, a ganhos interessantes no campo da liricização dos diálogos e do uso da ironia estrutural.

${ }^{22}$ Idem, ibidem, p. 114. 
Verão no Lago é uma das peças em que uma figuração de base simbólica apresenta-se como processo principal de tratamento da matéria representada. A questão central - a entrada de Donald, um adolescente de dezessete anos, na vida adulta, e a relutância de sua mãe, Mrs. Fenway, em aperceber-se disso - é abordada com estratégias que combinam as elipses e lacunas nos diálogos ao uso de elementos simbólicos em vários níveis de expressão e representação.

A técnica do contraste é empregada para caracterizar as personagens e sua inter-relação. Mrs. Fenway fala ininterruptamente dirigindo-se tanto ao filho como à empregada, Anna, com os quais passa a temporada de verão em um chalé junto a um grande lago: faz comentários e pedidos (muitas vezes desencontrados), queixa-se do calor sufocante e manifesta sua própria apreensão sobre o que lhe reserva o futuro, pois está recém-separada de seu marido. Donald é lacônico e distante, e responde por monossílabos às solicitações da mãe, e Anna é perspicaz e paciente ao lidar com a patroa, cujos hábitos demonstra conhecer sobejamente.

A verbosidade fátua de Mrs. Fenway dá margem à exposição de inúmeras incongruências que a caracterizam tanto em sua relação com o ex-marido, o filho e a empregada, como no que diz respeito ao círculo de amizades que frequenta e à forma como lida com as transformações iminentes que sua vida material provavelmente sofrerá com o recente divórcio.

Se o tratamento dramatúrgico dessa personagem se aproxima bastante do âmbito da comédia social, bem diferente é o que ocorre no caso de Donald. O contraponto entre o adolescente e a mãe é assinalado, no plano cênico, pela oposição entre a pesada imobilidade matronal dela e a ágil inquietude jovial dele. Mas é no campo dos diálogos que esse contraponto ganha um subtexto simbólico fundamental para a peça:

MRS. FENWAY: [...] (Pegando a carta) Seu pai diz aqui que é melhor você não fazer nenhum plano para a faculdade este outono, já que -

DONALD: Não!

MRS. FENWAY: O quê?

DONALD: Não leia mais nada!

MRS. FENWAY: Você é assim. Não consegue encarar nada que o desagrade. Quer continuar sendo criança o resto da vida. Bem, logo vai descobrir que não há como. Você vai ter que assumir algumas responsabilidades, agora que seu pai nos largou e provavelmente se envolveu com alguma mulherzinha vulgar!

DONALD: Eu não preciso fazer nada que não queira! (Ele se levanta e vai até a janela novamente) Não tenho que ser nada além de mim mesmo! (Olhando-a desesperadamente) Pelo amor de Deus, mãe, eu não quero ir para casa! Eu odeio aquilo! Eu odeio aquele lugar! Odeio! É como estar preso numa armadilha horrível! (Cobre o rosto e senta-se no peitoril da janela) Os muros de tijolos, o concreto e as - as escadas de emergência pretas! Elas são o que eu mais odeio - escadas de emergência! Será que não pensam que as pessoas que moram em apartamentos precisam escapar de qualquer outra coisa além de incêndios?

MRS. FENWAY: Donald! Eu queria que você parasse de falar assim, esquisito!

DONALD: Sonhei que estava numa delas noite passada.

MRS. FENWAY: Numa o que?

DONALD: Escada de emergência. Numa interminável escada de emergência preta. Eu corria, corria, subia e descia e nunca chegava a lugar algum! No fim eu parei de correr, não conseguia 
correr mais, e todo aquele ferro preto começou a me envolver como uma serpente! Eu não conseguia respirar.

MRS. FENWAY: Pare! No meu estado de nervos, é um crime me fazer ouvir essas coisas! O que você comeu antes de dormir ontem?

DONALD: (rindo de modo cínico) Isso, culpe minha digestão! - Estou saindo!

MRS. FENWAY: Para onde?

DONALD: Já falei! Pro lago. ${ }^{23}$

As imagens invocadas por Donald - os muros, a escada de incêndio transformando-se em serpente e o sufocamento final - perturbam Mrs. Fenway ao extremo por constituírem uma forma figurada de expressão e fugirem, assim, aos seus hábitos perceptivos. O amadurecimento que ela espera do filho está, de fato, em processo, mas longe dos mecanismos de convívio e de inserção social aos quais ela alude: ele se manifesta de forma agônica, tortuosa e estranha à sua percepção materna, como indica o conteúdo simbólico do sonho do menino.

A principal escolha formal da peça consiste, justamente, em figurar a entrada de Donald na vida adulta por meio de expedientes fortemente simbólicos, o que confere ao texto densidade de sentidos e economia de expressão: de um lado têmse o brilho das águas ao sol e a ideia do lago como local de suspensão do tempo, imagem evocada por Donald; de outro, a perturbação de Mrs. Fenway com o ruído produzido pelo relógio e o progressivo e sintomático ofuscamento de sua visão diante do brilho da superfície avistada pela janela.

Trata-se de um recurso de escritura que permite tratar de uma questão subjetiva e abstrata - a transição da adolescência à idade adulta - dando-lhe materialidade cênica e tessitura dialógica bastante econômicas e eficazes.

Sintomaticamente, é Anna que irá, no final, em obediência à própria Mrs. Fenway, relatar o afastamento definitivo de Donald para além do campo de visão, e simbolicamente para além do vínculo familiar:

MRS. FENWAY: Onde ele está agora? Não posso vê-lo.

ANNA: Ainda está nadando para longe.

MRS. FENWAY: Pra longe?

ANNA: Sim senhora. Ainda muito longe.

MRS. FENWAY: Por que não começa a voltar? Anna! Vá, corra até lá e fale para ele voltar. Rápido, rápido, antes que ele - (ela coloca a cabeça para fora da janela e grita.) Donald!

(Longa pausa. Anna lentamente leva a mão à garganta. Mrs. Fenway sai de perto da janela cambaleando.)

MRS. FENWAY: A luz do sol me cega. Não consigo mais vê-lo. Está tudo preto. Não enxergo nada. Onde ele está agora? Ele já deu a volta? (pausa) Estou tão fraca. Tonta. O que aconteceu? (ela se senta pesadamente em uma cadeira de vime no centro da sala) Traga-me um copo de água e minhas gotas. (pausa) O Donald já voltou para a margem?

(Anna vira-se devagar da janela enquanto faz o sinal da cruz.)

ANNA: Não.

(Pausa)

${ }^{23}$ Idem, ibidem, p. 63. 


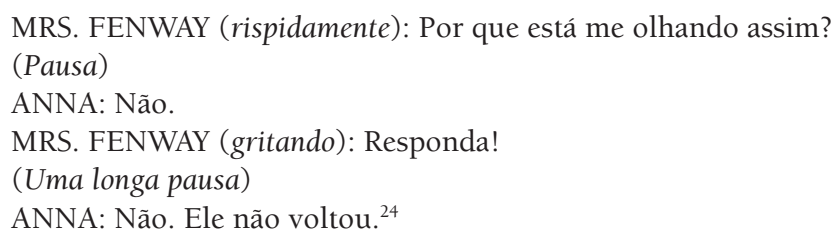

Embora nesse desfecho da peça o leitor e o espectador também "dependam" dos olhos e das respostas de Anna sobre o distanciamento de Donald no lago, são os silêncios e pausas dela que, para eles, carregam-se de sentido e revelam aquilo que Mrs. Fenway, em seu sintomático ofuscamento, não consegue (ou inconscientemente não deseja) enxergar.

A peça funciona com base na densidade e na expressividade lírica de suas imagens, e isso lhe permite tratar, de forma dramaturgicamente compacta, de algo que a escritura dramática convencional teria de abordar por meio de longo e minucioso processo de caracterização psicológica.

A afinidade de Tennessee Williams com esses expedientes de criação e de expressão é, sem dúvida, um dos elementos-chave para a sua grande afinidade com a estrutura da peça em um ato.

\section{V}

Os expedientes líricos empregados na escrita dramatúrgica de Tennessee Williams e o importante papel que desempenham em seu teatro podem levar leitores ou espectadores desavisados ou ingênuos a enxergarem nele um predomínio de elementos subjetivos e oníricos ligados à representação do indivíduo e da vida privada em detrimento de aspectos de representação social, econômica ou contextual.

Trata-se, na verdade, de uma percepção que encontra eco em parte da própria fortuna crítica do dramaturgo, especialmente por associar-se fortemente à avaliação, também amplamente disseminada, de que a matéria por excelência da dramaturgia de Tennessee provém da projeção de elementos da memória autobiográfica do autor.

Embora essa questão esteja fora daquilo que este artigo se propõe a discutir, é necessário dizer que se trata de uma avaliação à qual uma análise atenta das peças em um ato contrapõe fartas e importantes indicações em contrário.

Elementos de inspiração autobiográfica podem, de fato, ser detectados residualmente em várias das peças reunidas em Mr. Paradise and other plays, apresentando-se ligados, por exemplo, à representação de personagens dotadas de sensibilidade artística e intelectual (como em Verão no Lago), de homossexualidade expressa ou latente (como em E contar tristes histórias das mortes de travestis), e de um contexto fortemente impregnado da atmosfera social e histórica do sul dos

${ }^{24}$ Idem, ibidem, p. 73. 
Estados Unidos e mais particularmente de Nova Orléans (como em Estas são as escadas que você tem que vigiar e Obrigada, bom Espírito). Entretanto, nenhuma dessas formas de figuração se mostra, nas peças, desligada de uma representação crítica de aspectos como classe, gênero e ideologia.

Peças como A mulher do gordo e $O$ quarto rosa fornecem uma visão distanciada e nem um pouco complacente da classe média norte-americana das décadas de 1930-1940, e expõem fartamente, nos expedientes dialógicos anteriormente comentados, a incipiência de suas relações afetivas e o convencionalismo estreito e conservador de sua visão de mundo e das instituições e valores em que se apoiam.

Também Por que você fuma tanto, Lily? lança um olhar distanciado e questionador sobre a classe média, objetivando-o no emprego de um tratamento cênico de base expressionista.

É interessante a opção formal da peça no que diz respeito à centralidade de uma visão crítica dessa classe: o descompasso entre as pretensões sociais de Mrs. Yorke e sua situação financeira real fazem-na imaginar que a prosperidade possa ser resgatada por meio de um possível casamento da filha, Lily, que, por sua vez, rejeita e critica fortemente as expectativas maternas. Embora todo o segmento inicial do texto desenvolva e explore diferentes ângulos dessa tensão entre ambas, não é a relação conflitual entre elas que irá ocupar o epicentro da matéria representada, e sim a fantasmagoria internalizada pela moça na segunda parte da peça, constituída pela exacerbação dos preconceitos e estereótipos de classe que Mrs. Yorke personifica: a imagem da própria Lily, no espelho, falando involuntária e incontrolavelmente com a voz amplificada e onipresente da mãe; a narração, por essa voz, da relação dominadora e destrutiva que manteve com o marido, já morto; e por fim, a correlação que estabelece entre a sensibilidade intelectual dele e a que identifica nos gostos e hábitos da filha.

A intrusão da voz e do discurso de Mrs. Yorke, que em princípio se expressa por meio de Lily, prossegue e ecoa também quando esta cerra os lábios ou fecha os olhos. A dissociação entre personagem e voz, a onipresença tonitruante da fala materna, a reprodução indesejada de seu discurso, e, por fim, a repetição ouvida de chavões e cobranças característicos do pensamento materno compõem uma sequência cênica de impacto indiscutivelmente crítico. ${ }^{25}$

Sintomaticamente Lily é tratada na rubrica, a certa altura, como figura andrógina, de traços fortes, corpo anguloso, e que "passaria por um rapaz". ${ }^{26}$ Ao condensar nela traços que a aproximam da imagem masculina (e paterna), a peça reforça o contraste entre sua própria caracterização e a da mãe, e obviamente coloca em foco o papel convencionalmente imposto à mulher. Mas o faz sem que esses aspectos se dissociem da contundente representação crítica de estereótipos da classe média norte-americana tipificados no pensamento e no discurso de Mrs. Yorke: a aceitação inquestionada e servil do culto às aparências, o atrelamento preconi-

${ }^{25}$ Idem, ibidem, p. 52.

26 Idem, ibidem, p. 51. 
zado das relações familiares às metas de ascensão social, e o desapreço por toda forma de atividade alheia ou refratária à conquista do sucesso material.

A representação de questões de classe nas peças em um ato de Tennessee Williams se dá em parte considerável de sua produção - não só nos textos reunidos em Mr. Paradise and other plays, mas também nos que integram outras compilações, como 27 Wagons Full of Cotton and other plays.

A disseminação midiática de adaptações dos trabalhos do autor, associada à grande veiculação de certos padrões de leitura deles, contribuiu para que se cristalizassem a seu respeito algumas formas de apreciação não fundamentadas na análise das peças, ou pelo menos de um conjunto mais amplo e representativo delas.

Num contexto como o brasileiro, onde são escassas as traduções e mais ainda as edições recentes de seus trabalhos (exceção feita aos títulos que já integram o cânone), discutir a presença e a importância de uma perspectiva crítica na representação de questões de sociais em sua dramaturgia é tarefa que extrapola em muito o escopo deste artigo.

No que diz respeito ao volume de que estamos tratando, a representação de questões de classe e de ideologia apresenta-se com igual contundência e recursos formais diversificados em várias das outras peças. Fuga, por exemplo, lança mão de uma estrutura integralmente narrativa para dar voz a um grupo de prisioneiros que acompanham, pela janela da cela que ocupam em um campo de trabalhos forçados na Luisiânia, a empreitada temerária de um companheiro fugitivo. Obrigada, bom Espírito põe em foco o exercício de autoritarismo e preconceito que, invocando os preceitos da fé católica, branca e conservadora, desarticula o centro de atendimento espiritual de Mãe Duclos, uma médium negra e pobre de Nova Orléans.

O Palooka trata da efemeridade, da inconsistência e da fragilidade do mundo esportivo, impregnado da ideologia capitalista do sucesso como meta máxima. "Palooka", termo inspirado no nome de um personagem de tiras cômicas dos anos 1930 e 1940, designa um atleta esportivo (especialmente um boxeador) incompetente ou facilmente derrotado. Na peça refere-se ao personagem que será, depois, identificado como Galveston Joe, o campeão de outrora que conquistou glórias esportivas e fama e que agora, aos 38 anos, é uma figura frágil e combalida a ponto de não ser reconhecido pelo próprio estreante que o idolatrara na infância.

A estrutura da peça apoia-se na estratégia da reversão, na parte final, das aparências e sentidos sugeridos no início: o interlocutor ouvido com empolgação pelo rapaz prestes a estrear, e que lhe conta ter tido a honra de conhecer Galveston Joe pessoalmente, não é senão o próprio. Trata-se de uma tardia e desconcertante descoberta para o jovem nos minutos que precedem, ironicamente, a sua própria luta de estreia.

Tem inequívoco sentido crítico, na peça, o uso da ironia dramática, construída não pela explicitação da identidade do Palooka ao leitor ou espectador, mas pelo tom idealizado de que se reveste a fala do veterano ao jovem. No testemunho que dá sobre o campeão do passado insinua-se sutilmente a sombra da figura presente, decadente e esquecida: 
PALOOKA (acendendo um cigarro) - Fica calmo. Pra que queimar o couro da sua sapatilha? Senta aí. Já ouviu falar de um palooka chamado Galveston Joe?

GAROTO - Claro! Ele não era um palooka, ele era o campeão dos pesos meio-pesados.

PALOOKA - (com um leve sorriso) É, ele não era um palooka.

GAROTO - Você sabe que não.

PALOOKA - Sabe onde ele acabou?

GAROTO - Galveston Joe? Não sei, acho que deve estar aposentado a esta altura.

PALOOKA - Aposentado? É, aposentado. É. E encheu os bolsos de dinheiro.

GAROTO - Claro. Além de ser muito forte, ele era muito bom! Todos gostavam dele.

PALOOKA - Quando foi que você ouviu falar dele pela última vez?

GAROTO - Ah, não sei. Na época em que eu era garoto e vendia jornais. Ele era o meu herói naquela época. Eu tinha a foto dele na parede do meu quarto...

PALOOKA - É mesmo?

GAROTO - ...e eu costumava ficar exatamente em frente dela dando golpes e me imaginando igualzinho ao Galveston Joe: o campeão dos pesos meio-pesados.

PALOOKA - Por que não? Você está no caminho. ${ }^{27}$

A ironia dramática empregada tem ainda outra faceta em O Palooka: na menção do veterano ao sucesso e riqueza conquistados por Galveston Joe, insinua-se, para o leitor e o espectador, o avesso real de sua situação presente, que presumivelmente será também, um dia, a situação futura do garoto estreante. Os mecanismos de ascensão ao panteão idealizado do sucesso e da riqueza são representados, na peça, por meio da crítica à ideologia em que se apoiam e dos efeitos perversos que produzem, resumidos exemplarmente nas palavras do próprio Palooka ao treinador, no início, ao ouvir do vestiário o clamor do público durante a luta de um boxeador em fim de carreira:

PALOOKA - [...] Eles gostam de ver um Palooka velho perder o prumo. Ouve só a torcida: estão pedindo morte sangrenta. E provavelmente é o que vão ter. O coitado é muito velho, não tem resistência, é só acertar ele no olho e ele vai pro chão. Você deve achar engraçado eu chamar outro cara de velho. Não estou na flor da idade. Trinta e oito. Nos contratos de seguros ou na venda de apólices nos bancos, ou em qualquer outro ramo que não o boxe, iam dizer que você ainda é jovem com trinta e oito. Mas um lutador nessa idade é só um palooka sem forças, acabado. Ele começa falando de um jeito estranho, se esquiva de movimentos que não existem. $\mathrm{E}$ a multidão grita desse jeito pra ele porque querem ver ele nocauteado pelo golpe do outro, sem reação. Pode ser que há cinco ou dez anos atrás ele fosse o herói deles, o lutador favorito da torcida. Agora, com que merda eles se importam? [... $]^{28}$

O grande jogo passa tangencialmente pela questão do sucesso esportivo, ainda que ela não seja central em relação à matéria representada. A peça transcorre no sul dos Estados Unidos, na enfermaria masculina de um hospital municipal em que Tony Elson, uma estrela do futebol universitário norte-americano, recupera-se de uma intervenção que lhe salvou a perna. Os dois pacientes que dividem com ele

${ }^{27}$ Idem, ibidem, p. 31.

${ }^{28}$ Idem, ibidem, p. 29. 
o espaço são casos de grande gravidade: Dave, de vinte anos, tem grave anomalia cardíaca e é um paciente terminal; Walton, de 49, veterano da primeira guerra, deve passar por delicada cirurgia neurológica.

A representação de classes se apresenta por meio do contraste entre a situação social de Tony (atleta bem-sucedido, que tem família e dinheiro) e de Dave (paciente do sistema público que ocupa vaga destinada a não pagantes):

TONY: Outra noite ruim?

DAVE: Péssima. É como se eu não conseguisse respirar. Dez e meia pedi uma injeção. Era quase meia noite quando me deram.

TONY: Acho que eles não querem te dar muito daquela coisa.

DAVE: (tenso) Eu preciso. Eles sabem disso. Porque não me dão quando eu peço?

TONY: Eles querem que você aguente firme o máximo que conseguir.

DAVE: Não, eles sabem que estou no atendimento público. ${ }^{29}$

Embora o título, aludindo ao jogo, sugira que Tony possa ser a personagem central, o que tem centralidade na peça é a contraposição entre a situação do jogador e a de Dave: Tony anseia pela alta para que possa assistir da arquibancada ao segundo tempo da partida contra o Missouri, da qual não poderá participar; Dave deseja apenas conseguir respirar à noite e dormir.

DR. NORTH: Nós vamos arranjar um sedativo para você esta noite, Dave.

DAVE: Sedativo também não adianta. Não me faz parar de tossir à noite. Eu quero parar de tossir. Eu quero dormir um pouco. Não quero ficar aqui noite após noite olhando para o teto... e... e... na expectativa...

DR. NORTH: Na expectativa de que?

DAVE: De nada. (Ele vira-se de lado.) Desculpe o escândalo. Não queria.

DR. NORTH: Tudo bem, garoto. Estamos todos torcendo por você, sabia? ${ }^{30}$

A ideia do jogo ganha, assim, um tratamento simbólico: para Tony, a questão é a carreira, e ele reluta em aceitar que estará fora do jogo decisivo; para Dave, a questão é a vida, e ele sabe, embora não o diga, que também estará, em breve, "fora de campo".

Uma perspectiva simbólica de figuração é alavancada aqui, mais uma vez, pelo emprego da ironia dramática, construída pelo encadeamento de revelações feitas sucessivamente a Tony e a Dave. Tony fica sabendo da condição terminal de Dave enquanto aguarda a confirmação de sua própria alta. Dave é informado da morte de Walton ao perguntar sobre a demora de seu retorno à enfermaria após ser operado. As revelações feitas a um e a outro são presenciadas pelo leitor e pelo espectador, o que lhe dá conhecimento sobre a totalidade das situações e dos desdobramentos implicados. A matéria dramatúrgica tratada é, nesse processo, fortemente

29 Idem, ibidem, p. 77.

${ }^{30}$ Idem, ibidem, p. 85. 
alegorizada: a enfermaria é um espaço físico de passagem entre doença e cura ou entre vida e morte. A transitoriedade temporal e circunstancial marca os percursos dos pacientes, que convergem num primeiro momento e depois se separam. As condições e perspectivas de vida associadas às três personagens centrais (Tony, Dave e Walton) carregam-se de exemplaridade simbólica, figurando dramaturgicamente as perspectivas ligadas ao viver e ao morrer, cujos significados e implicações são tratados como relativos.

Fica patente na peça, mais uma vez, a afinidade de Tennessee Williams com os recursos simbólicos de dramaturgia, compatíveis, como já apontamos, com a concisão estrutural inerente à peça em um ato e com a contiguidade que ela apresenta em relação ao campo da linguagem poética.

Não se pode ignorar, no material assim constituído, a presença concreta de associações que remetem de forma crítica a questões de ordem social, seja sob o ângulo da já comentada representação de classes, seja no que se refere à função que acaba sendo desempenhada pelos comentários de Walton ao correlacionar a experiência extrema que viveu na guerra e a que enfrenta agora ante a possibilidade da morte:

WALTON - [...] Cirurgia no cérebro é um negócio delicado. (Sua voz torna-se suave e levemente trêmula.) Tudo pode acontecer. É isso aí. (Ele ri de novo.) Estava com muito medo ontem à noite. É. Só de pensar nisso. Deitado lá na cama tentando dormir. Não dormi nem um segundo. Só pensando. Talvez essa seja sua última noite, meu chapa! Essa ideia me bateu estranho. Não conseguia me acostumar. É diferente quando você está nas trincheiras. Aí as granadas estourando ao seu lado... as coisas explodindo... grandes estrondos, bum-bang... pega na veia e você fica meio louco e quase esquece de ficar com medo!... Mas à noite... sozinho... tentando dormir... e aquela ideia na sua cabeça o tempo todo... talvez essa seja a noite, meu chapa... não vai ter mais noites depois desta... Meu amigo! A coisa meio que te toca! Quando você é essa pessoa há quarenta e nove anos... sabe... você meio que se acostuma a ser você... e quando pensa em não ser você mais... ser nada... só morto... parece que... (Apressadamente acende outro cigarro.) Sabe o que eu fiz ontem à noite? Levantei da cama e abri a persiana! Eu levantei até o máximo! Levantei até abrir tudo, até o topo da janela!

DAVE: (com interesse) Pra que você fez isso?

WALTON: (comovido, depois de uma breve pausa) Para poder ver as estrelas!

DAVE: É? Ajudou?

WALTON: Claro. Sempre ajuda. Quando a gente está com medo, a melhor coisa é olhar as estrelas lá em cima. Isso é outra coisa que aprendi na França. Lembro de uma noite saindo da trincheira depois de um bombardeio pesado... Eu fiquei paralisado de medo... Andava que nem bêbado... Mal conseguia segurar a arma... De repente vi o céu de relance... Entre as nuvens de fumaça... Eu ri em voz alta. Tinha tantas estrelas lá no alto... Eu era só... Dá pra entender?

DAVE: É, mas o que isso de traz de bom?

WALTON: Não sei... Te faz sentir muito pequeno e sem importância, elas são tão frias e distantes... Você olha para elas e diz a si, bom, que importância tenho eu? Tem milhões como eu nascendo todos os dias! Entende? Você olha para aquelas estrelas e sabe que elas estavam lá milhares de anos antes de você chegar a terra... E vão estar lá milhares de anos depois que você se for! Elas meio que... representam... a eternidade ou coisa assim! E quando você pensa em uma coisa como a eternidade... uma coisa assim... (Faz um gesto vago com ambas as mãos.)

DAVE: É...É... 
WALTON: (sorrindo) Dá pra entender?

DAVE: (com um entendimento lento) É, eu sei o que você quer dizer... ${ }^{31}$

Camuflar a morte como dado existencial e geracional é uma das facetas do sistema de vida e pensamento inerente à cultura capitalista: a ideia das individualidades "sublimes" ou "heroicas", inerente à cultura capitalista, leva à aceitação tácita de que uma posteridade elevada e supostamente "eterna" pode ser atingida por meio delas, correspondendo a uma grandeza idealizada e situada além e acima da vida comum, da vida dos "ordinary men".

A fala de Walton sobre a contemplação do céu, em sua inconclusividade e suspensões de pensamento, descreve a tranquilidade que sentiu ao vislumbrar não uma possível morte heroica no campo de batalha, ou uma presumida transcendência sugerida pelas estrelas, mas a pequenez histórica e coletiva inerente à sua própria condição. Há um sentido épico latente não só no conteúdo exposto, mas também no fato de Walton falar a partir da materialidade de seu insight sobre os "milhões [...] nascendo todos os dias", evidenciando a percepção e a valorização de um processo humano e concreto de nascimento e vida que se perpetua para além do indivíduo e para além do fato particular de sua morte. Pode-se detectar aí um substrato épico latente na concepção da personagem, e na própria tessitura dramatúrgica da peça.

Não são poucos os pesquisadores e mesmo encenadores brasileiros que não hesitam em estabelecer associações entre a dramaturgia de Tennessee Williams e os padrões de um assim chamado "realismo psicológico". Embora não caiba aqui discutir as razões e implicações dessa associação, é importante ressaltar que a análise atenta dos padrões formais das peças em um ato do autor indica uma distância considerável de seu trabalho em relação a um "realismo" dramatúrgico ou cênico ou a uma "psicologização" apoiada em personagens individualizadas nos moldes característicos da forma dramática.

O Matadouro Municipal acrescenta aspectos relevantes a esse respeito, e o faz por meio de recursos situados entre o expressionismo e o épico. Isso ocorre não apenas porque as personagens interagem fora do âmbito de uma caracterização particularizante, mas também porque o próprio assunto e seu tratamento formal aproximam-na da estrutura e do tom de certos esquetes de teatro político. A rubrica de abertura parece antecipar alguns elementos nessa direção:

Calçada de uma rua. A rua em si não aparece. Atrás da calçada há um muro de concreto cinza sobre o qual alguns cartazes de um ditador militar estão colados e na parte inferior deles há a palavra "Viva". Entardecer de um dia de verão. Um rapaz e uma moça, estudantes universitários, caminham pela calçada. A moça chora e o rapaz carrega uma bandeira enrolada. Ouve-se ao longe música de banda sendo tocada em um desfile: o som da banda é ouvido ao fundo até o fim da peça. ${ }^{32}$

${ }^{31}$ Idem, ibidem, p. 95-96.

${ }^{32}$ Idem, ibidem. 
O Matadouro Municipal do título é o local para o qual um funcionário público acaba de ser transferido após ter sido denunciado como perturbador da ordem pública vigente, e é justamente ao Rapaz universitário mencionado na rubrica que ele se dirige em busca de informação.

\begin{abstract}
FUNCIONÁRIO: Você poderia, teria a gentileza de me dizer onde fica o Matadouro Municipal? RAPAZ: Você quer dizer o...??

FUNCIONÁRIO: É, o Matadouro Municipal. Acho que eu perdi o papel em que tinha anotado o endereço e já estou atrasado.

RAPAZ: Trabalha no Matadouro?

FUNCIONÁRIO: Ah, não, não. Quer dizer, até ontem eu trabalhava no Tesouro Nacional como funcionário administrativo, mas fui dispensado e hoje fui condenado.

RAPAZ: Condenado por quê? Você sabe?

FUNCIONÁRIO: Há várias possibilidades. Fiz uma coisa idiota na semana passada. Estava passando por uma tabacaria e na vitrine da loja havia uma engenhoca de arame, um, um, uma esteira de corrida, uma gaiola giratória. Tinha um bichinho lá dentro, um esquilo, ou uma tâmia, alguma coisa assim, e ele ficava correndo, correndo, correndo na gaiola, na esteira, e parecia - assustado, pra mim parecia que estava em pânico. Então eu fiz uma coisa muito idiota, entrei na loja e falei com o dono sobre o bichinho na gaiola giratória. Perguntei se a criatura saía da esteira de vez em quando ou se tinha que ficar correndo o tempo todo, e o homem da loja, o dono da loja, ficou numa fúria terrível com as minhas perguntas. Ele me agarrou pelo casaco, arrancou minha carteira do bolso, anotou meu nome, endereço e local de trabalho e disse que ia me denunciar por interferir em coisas que não me diziam respeito. Acho que ele deve ter me denunciado, pois recebi uma ordem pra me dirigir ao Matadouro Municipal. Mas posso ter sido enviado por outro motivo também. Quando minha filha foi selecionada para o Bordel Municipal, eu, eu escrevi uma apelação ao... ${ }^{33}$
\end{abstract}

O Rapaz é presumivelmente um militante político prestes a executar um atentado que implica grande risco, como sugere o diálogo inicial que tivera com a moça referida na rubrica:

\author{
MOÇA: Não precisava ser você! \\ RAPAZ: Para com isso! \\ MOÇA: Podia ser uma pessoa mais velha, alguém doente ou feio! ${ }^{34}$
}

Tanto a rubrica de abertura como os diálogos que o Rapaz trava com a Moça e a seguir com o Funcionário contêm pistas implícitas que contextualizam a cena no campo político de uma ditadura: há cartazes de um ditador pelos muros, e não há certeza, por parte do Funcionário, sobre a origem e o motivo da denúncia que teriam acarretado a sua transferência. A narrativa do Funcionário indica que ele próprio julga ter cometido um erro ao questionar a intermitência da corrida do animalzinho na esteira, embora não esteja certo de que esse tenha sido o motivo de sua punição. A reação violenta do dono da tabacaria sugere que a pergunta que

\footnotetext{
${ }^{33}$ Idem, ibidem, p. 160.

${ }^{34}$ Idem, ibidem, p. 159.
} 
ouviu está de tal forma fora do aceitável a ponto de lhe permitir arrancar a carteira e os documentos do bolso do Funcionário e denunciá-lo por perturbação da ordem. Embora cogite a existência de vários possíveis motivos para a transferência recebida, o Funcionário não recebeu nenhum esclarecimento a respeito, o que reforça a ideia de que a sua punição se deu de modo sumário e que se está em um regime de exceção. E finalmente, ao contar ao rapaz sobre a "seleção" de sua filha para trabalhar no "Bordel Municipal", ele deixa entrever um sistema político autoritário em que a denúncia e a prostituição são usuais e fazem parte do aparato institucional vigente.

O Funcionário é um trabalhador administrativo, e a sua transferência para o Matadouro Municipal, localizado em endereço que ele próprio desconhece, lhe havia sido anunciada verbalmente por telefonema e não por notificação escrita, o que a faz soar sinistra já que se está no contexto de uma ditadura militar. Isso, porém, nem de longe abala a sua determinação em cumprir a ordem e apresentar-se no local.

Os expedientes dramatúrgicos têm clara base expressionista e o Funcionário e as circunstâncias relacionadas à sua condenação fazem lembrar, ainda que remotamente, de características de A máquina de somar, de Elmer Rice, escrita em 1923. $O$ foco central e as questões relacionadas apresentam traços de afinidades com o épico: a natureza tipificada das personagens, o emprego da narrativa na fala inicial do Funcionário, o fato de a peça fazer uso de um contexto político que possui função estrutural e não apenas incidental, e, por fim, o fato de a peça explorar o contraponto entre duas perspectivas ideológicas antagônicas, associadas respectivamente ao Rapaz militante e ao Funcionário administrativo.

Apesar das diferenças marcantes, o Rapaz e o Funcionário compartilham de uma característica comum, que é a disposição em servir integralmente as entidades a que se ligam: o Rapaz na esfera do ativismo revolucionário, e o Funcionário na área burocrático-administrativa. O que a peça coloca em foco, na sequência, é uma questão politicamente controvertida: pode o cego cumprimento da ordem, que caracteriza o sentido de vida, convívio e trabalho do Funcionário, ser posto a serviço de uma causa revolucionária? Pode tão inabalável disposição em obedecer cegamente ser instrumentalizada em prol de uma ação politicamente transformadora?

O Rapaz esgotou inutilmente todos os argumentos que lhe ocorreram para convencer o Funcionário a fugir e a tentar salvar-se. Em vista disso, assumindo voz de comando, transfere ao homem as instruções para a execução do atentado, que deve acontecer nos minutos que se seguem:

RAPAZ: O senhor vai fazer exatamente o que eu digo. O senhor é meu escravo e eu seu comandante. Então, agora. Daqui a pouco a parada vai passar bem aqui. O carro do General é o primeiro atrás das motocicletas. Entendeu?

FUNCIONÁRIO: Entendi, mas...

RAPAZ: Diga apenas sim. Sem mas.

FUNCIONÁRIO: Sim.

RAPAZ: Ótimo. Quando a primeira limusine estiver quase passando por aqui, o senhor grita "Viva, Viva!", agita a bandeira e ao mesmo tempo corre pela rua. E antes que eles o parem, o 
senhor dispara este revólver, carregado de munição, direto na cara e no peito do General, depressa, bem depressa, o mais rápido que puder. Certo, escravo? Entendido?

FUNCIONÁRIO: Certo.

RAPAZ: Vai ser mais rápido e mais fácil para o senhor do que ir ao compromisso no Matadouro Municipal e seu nome e sua foto estarão na primeira página dos jornais do mundo todo. Entendeu?

FUNCIONÁRIO: Entendi. ${ }^{35}$

Os sentidos do leitor e do espectador aguçam-se com a aproximação da parada militar, indicada pela música. As ordens do Rapaz parecem ter sido tacitamente assimiladas pelo Funcionário, e o Rapaz procura reforçá-las com um argumento final:

RAPAZ: Certo, agora o senhor fica que eu vou embora. Lembre-se que meus olhos e os olhos do mundo inteiro estão voltados para o senhor. Por acaso, o senhor pediu informação a um desconhecido em uma rua e sua vida sem sentido alcança a glória e sua morte vira a morte de um herói. Adeus. Me dê um abraço. (Ele puxa o homem para seus braços com força e depois o afasta.) Caro escravo, santo imortal, mártir e herói! ${ }^{36}$

A peça encerra-se, como outras de Mr. Paradise and other plays, com reversão total de expectativas: o atentado não se realiza, pois o Funcionário, presumivelmente pela primeira vez, executa apenas parcialmente as ordens recebidas e detém-se antes de disparar os tiros. Ao desobedecer ao Rapaz, o homem obedece ao sistema com resignação sacrificial. A culminação esperada não se efetiva, e o desfecho, em sua perturbadora inconclusividade, cria uma tensão crítica à qual nenhum dos elementos da peça escapa.

$\mathrm{O}$ que se encontra em foco na peça não são as motivações que teriam levado o Rapaz a transferir a um estranho a responsabilidade do ato pelo qual estava disposto a empenhar a própria vida, ou o que teria levado o Funcionário a desistir da ideia de tentar salvar-se e a tão passivamente retomar o caminho rumo ao que será provavelmente a sua morte.

O sentido político a ser extraído não tem caráter referencial mas estrutural: o Funcionário age com base no princípio da obediência, que assimilou durante a vida inteira; o Rapaz preserva-se ao procurar instrumentalizar essa obediência inelutável à causa, mas acaba determinando, involuntariamente, o fracasso da ação programada. A morte heroica como redenção de uma vida sem sentido é um argumento politicamente equivocado. Ao final, nada se transforma: o ditador não é executado, seja lá quais forem as consequências e implicações disso. Vendo-se na situação de optar entre duas formas presumíveis de morte, o Funcionário escolhe aquela que, apesar de tudo, o preserva naquilo que sempre foi, ou seja, um obediente serviçal que não questiona.

35 Idem, ibidem, p. 165.
${ }^{36}$ Idem, ibidem. 


\section{VI}

O repertório amplo e diversificado de expedientes de criação e expressão empregados em Mr. Paradise and other plays situa-se indiscutivelmente fora do âmbito do realismo ao qual muitos associam o trabalho de Tennessee Williams. Frutos do exercício dirigido e constante de escritura do autor, os textos apresentam fôlego crítico indiscutível com relação à ideologia do American Way of Life, e distendem a forma do drama moderno para além dos limites da representação das subjetividades e das reminiscências autobiográficas. A estrutura concisa da peça em um ato, tal como praticada pelo autor, potencializa inúmeros aspectos simbólicos, alegóricos e épico-líricos que conferem materialidade ao tratamento dramatúrgico de contradições cruciais da sociedade à sua volta. 